\title{
Pemanfaatan Aplikasi Benime untuk Pembelajaran Mufradat Siswa Kelas 1 di MIN 1 Solok
}

\author{
Amrina \\ Institut Agama Islam Negeri Batusangkar, Sumatera Barat, Indonesia \\ amrina@iainbatusangkar.ac.id
}

Adam Mudinillah

Sekolah Tinggi Agama Islam Al-Hikmah Pariangan Batusangkar, Sumatera Barat, Indonesia adammudinillah@staialhikmahpariangan.ac.id

Fadilatu Ulya

Institut Agama Islam Negeri Batusangkar, Sumatera Barat, Indonesia fadilla010920@gmail.com

\begin{abstract}
This researcher aims to introduce the application of Benime in the subject of Mufradat. Which mufradat is the main concept for learning Arabic and part of the science of Arabic language that expresses with respect to the objectification of a word and also one of the elements that should be mastered in learning about a foreign language. With this Benime application Mufradat will be displayed in the form of Video and there are sounds and animations to attract learners in learning Mufradat. This study uses a quantitative research method which is a type of pradigm research, a quantitative approach based on the paradigm in which the research is able to plan and realize the transition about the world around. In this case, the object of research is 1st grade students in MIN 1 solok. The results of this study provide great benefits to improve the unique ability of learners. In accordance with what was presented by the Arabic language teacher,
\end{abstract}


that this Benime application is very helpful in providing lesson materials, because the video created contains animated elements and is in accordance with the textbook.

Keywords: App Benime, Mufradat, Solok

$$
\begin{aligned}
& \text { ملخص } \\
& \text { يهدف هذا الباحث إلى التعريف بتطبيق بنيم في موضوع المفردات. أي مفردات هو المفهوم ملحمث } \\
& \text { الأسساسي لتعلم اللغة العربية وجزء من علم اللغة العربية الذي يعبر عنه فيما يتعلق بتشيبء } \\
& \text { كلمة وأيضًا أحد العناصر التي يجب إتقاها في تعلم لغة أجنبية. مع هذا تطبيق Benime } \\
& \text { سيتم عرض المفردات على شكل فيديو وهناك أصوات ورسوم متحركة تجذب المتعلمين في } \\
& \text { تعلم المفردات. تستخدم هذه الدراسة أسلوب البحث الكمي وهو نوع من البحث العملي ، وهو } \\
& \text { نهج كمي يعتمد على النموذج الذي يكون فيا البحث قادرًا على التخطيط وتحقيق الانتقال } \\
& \text { حول العالم. في هذه الحالة ، يكون موضوع البحث هو طلاب الصف الأول في } 1 \text { MIN } 1 \text { هون } \\
& \text { Solok } \\
& \text { قدمه مدرس اللغة العربية ، فإن تطبيق Benime هذا مفيد جدًا في توفير مواد الدرس ، لأن } \\
& \text { الفيديو الذي تم إنشاؤه يحتوي على عناصر متحركة ويتوافق مع الكتاب المدرسي. }
\end{aligned}
$$

\begin{abstract}
Abstrak
Penelitiain ini bertujuan untuk mengenalkan aplikasi Benime dalam mata pelajaran Mufradat. Yang mana mufradat adalah konsep utama untuk mempelajari bahasa Arab dan bagian dari ilmu bahasa Arab yang mengekspresikan berkenaan dengan pembendaan suatu kata dan juga salah satu elemen yang patut dikuasai dalam belajar mengenai bahasa asing.Dengan aplikasi Benime ini Mufradat akan dipaparkan dalam bentuk Video dan ada suara serta animasi untuk menarik peserta didik dalam belajar Mufradat. Penelitian ini menggunakan metode penelitiankuantitatif yang merupakan jenis penelitian pradigma, penghampiran kuantitatif berdasarkan paradigma yang dalam pertimbangannya bahwa penelitian mampu merencanakan dan mewujudkan peralihan tentang dunia sekitar. Dalam hal ini objek penelitiannya adalah siswa kelas 1 di MIN 1 solok. Hasil peneltian ini memberikan manfaat yang besar untuk meningkatkan kemampuan mufradat peserta didik. Sesuai dengan dengan yang disampaikan oleh guru bahasa Arab, bahwa aplikasi Benime ini sangat membantu dalam memberikan materi pelajaran, karena video yang dibuat mengandung unsur animasi dan sesuai dengan buku pelajaran.
\end{abstract}

Kata kunci:Aplikasi Benime, Mufradat, Solok 


\section{A. PENDAHULUAN}

Dengan seiring berjalannya zaman dari masa ke masa, serta berkembangnya teknologi hingga saat sekarang semuanya berubah, perubahan teknologi harus kita ikuti karena perubahan teknologi berkaitan erat dengan perkembangan ilmu pengetahuan (Nurdyansyah, 2017) Sebenarnya pendidikan secara umum yaitu untuk menetapkan teknologi untuk pencapaian pendidikan.Dari penjelasan yang telah di jelaskan tersebut, bisa kita mengetahuinya bahwasanya teknologi pendidikan ialah suatu cara untuk merubah dan menerapkan budi pekerti, yang baik dalam dunia pendidikan. Berkembangnya teknologi pendidikan pada masa sekarng patut kita beri antusias dengan cara mengikutinya. Karena perubahan ini sangat memengaruhi kepada perubahan kehidupan kita (Akbar \& Noviani, 2019).

Pendidikan adalah keinginan buat mengembangkan perilaku baik, daya pikir dan kesehatan anak-anak, mengembangkan kesempurnaan hidup dan membangkitkan anak yang sejalan dengan lingkungan di masyarakat (Ki Hajar Dewantara,13). Pengajaran di dalam lughoh arabiyyah di namakan tarbiyyah, yang di ambil dari kata awal Rabba Sya'i, Yarbu atau Rabba'an yang artinya tumbuh dan berkembang. Allah subhanahu Wa Ta'ala mengatakan kata tarbiyah bermakna tumbuh dalam firmanNya Surat Ar-ruumayat 39, dan dalam Surat Fushshilat ayat 39, dikemukakan oleh beberapa ahli ulama lain dengan arti tarbiyah yaitu besar dan berkembang (Wahidin, 2017). Sedangkan untuk yang dijelaskan di kamus besar bahasa Indonesia pendidikan ialah sistem pengalihan sudut pandang dan pendataan diri individu ataupun serangkaian individu yang bermakna untuk mematangkan Insan lewat cara petunjuk, dan pelatihan, prosedur kerja, dan cara membimbing, jadi bisa kita simpulkan bahwa pendidikan ialah usaha membantu anak semenjak hadir bakal dari keberhasilan kematangan fisik dan jiwa untuk hubungan bumi dan dunianya. Pendidikan juga dapat dikatakan sebagai cara untuk mengembangkan kapasitas manusia supaya memperoleh keahlian sosial dan pertumbuhan pribadi dengan publik dan kawasan adat lingkungannya. Selain 
dari penjelasan tersebut pendidikan ialah suatu cara untuk memanusiakan suatu individu sebagaimana individu itu diharapkan bisa untuk mengetahui pribadinya individu lain, kawasan dan adat istiadatnya. Karena inilah pendidikan tidak akan bisa terungkai dari adat yang melingkupi sebagai komoditas dari sasaran pendidikan yaitu mempertajam rasa, harapan dan Kreasi. Pemerolehan dari tujuan pendidikan ini menumbuhkan sanggahan sepanjang waktu antara diantaranya adalah pertikaian adat (Ibrahim, 2013).

Pendidikan ialah suatu dasar yang sering kita katakan dan yang mana di mata masyarakat dipandang salah karena pengertian pendidikan dibatasi hanya untuk pengajaran saja.Sedangkan arti dari pengajaran tersebut sangat sedikit dari pendidikan. Pengajaran perilaku yang diartikan examine memiliki penjelasan yang lebih kekecilan dibandingkan dengan pengertian pendidikan. Efek dari kontraksi makna pendidikan melahirkan pengajaran ini melalui prinsip apa dan bagaimana cara dalam pendidikan yang dapat kita katakan sama dengan apa dan bagaimana cara suatu pengajaran (Suriansyah, 2011).

Pendidikan ialah suatu bekal dasar bagi kita untuk menjadi generasi yang berkualitas. Sebagaimana yang di jelaskan dalam undang undang sidiknas yaitu upaya esensi dan sahaja untuk melahirkan situasi belajar dan prosedur pembelajaran supaya kita bisa secara aktiv untuk megembangkan kemepuan diri kita untuk memperoleh daya kebetinan agama, pengendalian diri, kemahiran individu, prilaku baik dan jua suatu seni yang di perlakukan dirinya, masyarakat bangsa dan negara (Emtha, 2014).

Dalam alur dunia pendidikan posisi guru sangat lah signifikan dan kita juga memerlukan guru yang berpotensi profeisional.potensi profesional guru dapat dikatakan sebagai setelan pengetahuan, keterampian, pengalaman yang di miliki dan dikuasai oleh guru sebagaimana untuk menjalankan tugasnya sebagai guru.kompetensi profesinal yang dimiliki guru adalah suatu keharusan sebagaimana dalam berupaya untuk memajukan mutu suatu pendidikan, dalam pandangan islam kompetensi profesional guru ialah menangkap tiga hal yaitu, subjektif keagamaan dan juga sosial keagamaan (Hasanah, 2015). 
Belajar dan pembelajaran adalah istilah yang terdapat di dalam dunia pendidikan. Belajar merupakan kegiatan yang di kerjakan oleh siswa yang disadari dan di sengaja. Kegiatan tersebut merusak pada kegigihan kita dalam mengerjakan bagian psikologis yang mengharuskan keadaan berubah pada dirinya. Sedangkan pembelajaran ialah metode pengontrolan, mengorganisasi tempat yang ada di sekeliling siswa. Pemerintahan juga telah menetapkan undang undang tentang sistem pendidikan nasional, maka pembelajaran merupakan prosedur ikatan pendidikan lewat siswa dan asal muasal belajar beroperasi dalam suatu zona belajar (pane,2017).

Pemerintah juga telah menetapkan undang- undang mengenai pendidikan yaitu mengenai sistem pendidikan nasional ialah pengembang pendidikan yang berkontribusi sebagai pendidik, dosen, vasilisator yang berkontribusi dalam pendidikan. pembelajaran juga dapat kita simpulkan sebagai kegiatan yang telah direncanakan oleh pengajar sebagai upaya untuk mencerdikkan kehidupan umat, dan juga merupakan suatu cara pengembang dari pendidikan yang ada di indonesia (Kirom, 2017).

Secara garis besar belajar bisa diartikan sebagai reaksi untuk peralihan prilaku, efek dari korelasi kita sebagai individu dengan linkungannya. Prilaku juga dikatakan memliki arti yang sangat ekstensif. Dalam hal terebut melingkupi, wawasan, penangkapan, kecakapan prilaku, dan lain sebagainya. Dalam arti lain menyatakan bahwa belajar ialah suatu upaya yang kita lakukan untuk mendapatkan sesuatu peralian sikap yang baru totalitas dari konsekuensi pengalaman kita dalam berhubungan dengan lingkungannya (Takdir, 2020).

Belajar ialah salah satu cara baik yang dapat kita lakukan sebagai peralihan dari tidak tahu menjadi tahu, dari tidak mempunyai prilaku baik menjadi mempunyai prilaku baik, dan dari tidak ahli menjadi ahli mengerjakan sesuatu. Tindakan mengajar tidak bisa kita lepaskan dari yang namanya belajar, karena dua duanya memiliki arti yang tidak sama tapi serupa seperti halnya sebuah mata uang. Mengajar ialah suatu usaha yang dilakukan guru 
agar kita sebagai siswa belajar. Belajar ialah suatu cara awal dari pertumbuhan hidup kita (Nurjati, 2002).

Pelaksanaan proses belajar mengajar juga bisa di artikan sebagai suatu gerakan yang amat utama dalam pendidikan. Belajar dan mengajar juga merupakan serangkaian kegiatan yang telah direncanakan oleh pendidik untuk peserta didik, agar bisa meraih suatu maksud dari pendidikan yang sudah di tetapkan. Yang mana usaha dari pembelajaran kita ini bersifat edukatif dan inspiratif yang dapat di ukur di akhir pembelajaran untuk menentukan apakah tujuan pendidikan telah tercapai (Hanafy, 2014).

Bahasa merupakan instrumen bacaan yang sangat diperlukan dalam berkorelasi melalui siapa saja yang ada di dunia, mempunyai fungsi untuk mempermudah komunikasi dengan yang lain. Bahasa ialah satu instrumen wacana yang unggul, inovatif bagi manusia untuk mengungkapkan gagasan. Bahasa tidak berpotensi terhambat dari aktivitas manusia Karena manusia itu sendiri yang memakai bahasa itu untuk keseharian. Dengan bahasa yang lain bahasa Arab yang memiliki keutamaan, sebab kualitas notulen yang berpangkat tinggi oleh mereka yang mengalami sastra Arab dan dapat digariskan sebagai bahasa dalam Alquran yang menglafaskan firman Allah. Karena terdapat di dalamnya usluk bahasa yang indah dan menakjubkan bagi manusia dan tidak ada seorangpun yang dapat menyanyinya (Takdir, 2020). Dalam bahasa arab dapat kita temukan istilah al-lughah al-ajnabiyah atau sering di katakan bahasa lain yaitu bahasa yang di pakai oleh orang asing. Dalam kamus besar bahasa Indonesia juga di artikan bahwa "asing" ialah hal yang berasas dari mancanegara atau luar kawasan kita khususnya bahasa arab yang ada di negeri kita Indonesia. Bahasa arab merupakan prosesif yang muncul dan membanyak yang sesuai dengan bermekar dan berlipatnya kita menggunakan bahasa tersebut. Keabsahan bahwa dalam kehidupan kita membuat beranjak memajukan sejadi-jadinya presensi kita sebagai manusia terpelajar dan beriman dan beragama (Tamaji,2020). 
Termasuk mata pelajaran yang penting bagi kita sebagai umat islam terutama yang ada di Indonesia ialah bahasa arab. Bahasa arab merupakan pelajaran yang dipelajari dari sekolah dasar kelas satu sampai kuliah di perguruan tinggi baik itu PTAI maupun PTU. Bahasa arab juga dikataan bahasa agama umat Islam. Oleh karena itu konsekuensinya untuk mengetahui ilmuilmu ajaran agama Islam disyaratkan memiliki kemampuan bahasa Arab. Karena asal dari ilmu-ilmu ajaran agama Islam itu di tulis dengan bahasa Arab. Selanjutnya bahasa Arab dan agama Islam disebut dengan dua sisi mata uang yang tidak bisa di pisahkan. Sedangkan jika bahasa Arab dikatakan masuk dalam golongan bahasa asing, lalu efek yang muncul ialah bahasa Arab tidak di posisikan untuk bahasa bacaan yang tidak untuk syarat mengerti tentang ajaran agama Islam (Helmanto, 2020)

Salah satu elemen yang banyak diabaikan dan bersifat sangat menunjang pendidikan yaitu kurikulum. Ada ruang yang hakikatnya besar di miliki oleh kurikulum, karena secara garis besar kurikulum adalah tujuan dari pendidikan suatu bangsa dan pemaparan dari pencapaian dan hasil. Berdasarkan pernyataan di atas dapat di artikan juga posisi kurikulum sebagai kunci dari gambaran nilai yang akan ditransformasikan terhadap peserta didik. Dalam faktor baik internal maupun eksternal kurikulum memiliki arah dan tujuan pendidikan yang akan melalui pergeseran dan perubahan seiring dengan gerakan perubahan sosial (Bahri, 2017).

Dengan kurikulum diharapkan mampu menghasilkan generasi yang mempunyai akhlak baik, kreatif, inovatif dan menjadi orang yang berguna, yang memiliki kecakapan. Kurikulum juga di sebut sebagai jantungnya suatu sekolah. Kurikulum ialah satu pekerjaan yang di rancang serta di laksanakan untuk mencapai tujuan. Oleh sebab sebagai penyelenggara satu pendidikan perlu satu konsep yang di fungsikan sebagai alat yang terus bisa di rubah selaras dengan perkembngan masa. Hal itu mencakup tengtang struktur kurikulum dan kurikulum pendidikan yang berlandaskan makna, struktur kurikulum, serta karakternya. Menurut al-Shaybani di kutip dari Hasan 
Langgulung (1985; 145) kurikulum ialah tumpukan proses pembelajaran, budaya, pembelajaran sosial, keolahragaan, dan keiilmuan seni yang tersedia di lembaga pendidikan untuk setiap siswa baik di dalam walaupun di luar lembaga pendidikan yang bertujuan untuk memajukan keseluruhan aspek aspek di dalam serta mengubah perilaku sesuai tujuan pendidikan (Hermawan et al., 2020).

Selaras dalam pengembangan, arti kurikulum banyak mengalami perubahan pengertian, kurikulum tidak hanya diartikan sebagai sekumpulan pelajaran yang wajib di berikan serta dikuasi oleh peserta didik, namun lebih lebar lagi dengan segala suatu yang wajib dilaksanakan dalam proses belajar yang di alami oleh pendidik dan peserta didik. Di dalam Undang-Undang sistem pendidikan Nasional Tahun 1989 Bab 1 pasal 1 dikatakan bahwa kurikulum ialah alat terencana dan aturan serta materi belajar dan metode yang digunakan untuk menyelenggarakan program belajar (Wafi, 2017).

Mempelajari bahasa arab merupakan suatu usaha yang tidak mudah, sebab bahasa arab adalah bahasa yang tidak sering kita dengar khusunya yang berada di Indonesia dan juga kesusahan untuk menerapkannya dalam kehidupan sehari-hari. Kita sebagai umat islam perlu mempelajari bahasa arab sebab lafaz yang kita baca di dalam al-Quran sebagai kitab suci umat islam, karena dengan kita mengetahui dan memahami bahasa arab kita umat islam bisa mengetahui dan memahami ajaran ilmu agama. Bahasa arab juga dapat kita katakan bahasa lainyang paling di minati dan kita pelajari khususnya kita yang berada di indonesia. Dengan demikian kita harus mengkaji bagaimana pembelajaran bahasa yang tepat untuk kita yang non-arab. Pemebelajaran bahasa lain termasuk bahasa arab ini bisa kita kerjakan dg cara dan metode yang baik atau relefan.Demikian hal nya dengan mempelajari suatu kosa kata(Hijriyah, 2018).

Untuk menguasai bahasa arab itu sendiri perlu adanya pembelajaran karena memperoleh bahasa asing bagi seorang pembelajar bahasa adalah dengan pembelajaran. Mempelajari kosa kata ialah hal yang mendasar dalam 
kita mempelajari bahasa lain seperti bahasa arab.Kosa kata (mufradat) sendiri merupakan salah satu unsur penting dalam suatu bahasa sebagaimana bahasa yang lain bahasa Arab sendiri juga mempunyai ribuan kosa kata (Mada, 2018).

Mufradat ialah bagian dari ilmu bahasa Arab yang mengekspresikan berkenaan dengan pembendaraan suatu kata dan juga salah satu elemen yang patut kita kuasai dalam belajar mengenai bahasa asing agar mendapatkan keahlian berkomunikasi (Hasbulloh, 2018). Pembelajaran mufradat pada MIN 1 Solok tersebut masih berharap pada buku teks, guru belum mencoba aplikasi berbasis apapun untuk meningkatkan dan memotivasi siswa dalam pembelajaran mufradat, dikarenakan terbatasnya guru dalam bidang teknologi dan guru juga tidak pernah mengikuti pelatihan media pembelajaran yang berkaitan dengan aplikasi komputer.

Pembelajaran bahasa Arab dikatakan sukses apabila pendidik memiliki teknik yang menarik dan juga benar dalam pembelajaran. Disamping itu pembelajaran harus memenuhi penciptaan dan pintasan dalam pemakaian teknik di masing-masing operasi dalam belajar-mengajar seiring dengan peralihan pandangan dan ketertarikan siswa terhadap substansi yang di sampaikan. Pada era globalisasi ini, bukanlah hal yang asing lagi bagi kita mempelajari bahasa Arab sebagaimana yag telah kita rasakan sudah lazim bagi sekolah-sekolah untuk mengajarkan materi bahasa arab sebagai materi yang di ajarkan. Dengan begitu membuktikan bahwa orang Indonesia telah menyadari mempelajari bahasa Arab itu sangatlah penting, khusunya bagi umat Islam. Kita benar-benar di haruskan mempelajari bahasa Arab dalam rangka untuk keperluan kita sebagai umat Islam. Jika kita tidak mempelajari bahasa Arab maka kita akan susah untuk memahami dan mengaplikasikan ilmu Islam atau ajaran Islam . Dengan demikian, kita harus memelajari bahasa Arab dari sekolah dasar (ibtidaiyah) dengan persiapan yang sangat mantap melalui empat keterampilan bahasa Arab yang di ajarkan secara utuh di antaranya istima (mendengarkan), kalam (berbicara), qara'a (membaca), dan kitabah (menulis)(Albantani, 2018). 
Agar terwujudnya pedidikan yang berkualitas kita memerlukan guru atau tenaga pendidik yang bisa selalu siap untuk berperan sebagai guru profesional baik di sekolah maupun di lingkup masyarakat. Seiring dengan hal tersebut sehingga tuntutan kompetensi guru profesinal harus menyesuaikan dengan perkembangan tersebutsejalan pada perkembangannya imu pengetahuan dan teknologidengan demikian pilihan sumber belajar dan media yang menunjang pembelajaran memiliki banyak pilihan, di antaranya: modul, buku teks, overhead transparansi, video, film, tape recorder, televisi, penggunaan komputer, internet dan lain sebagainya. Eksistensi media yang di gunakan harus sepadan dengan unsur situasi belajar (Jennah, 2009).

Instrumen yang sangat berperan untuk ikut serta dalam menentukan kesuksesan usaha belajar mengajar ialah media yang dijadikan alat bantu dalam proses belajar mengajar. Sehingga keberadaannya dapat memberikan gerakan secara langsung dengan tersendirinya kepada peserta didik. Menurut Gerlach dan Ely, bahwa media jika dipahami secara garis besar ialah insan, bahan ajar atau komponen untuk bangun keadaan menjadikan peserta didik bisa mendapatkan ilmu pengetahuan, terampil, dan perilaku. Di dalam hal ini, pendidik ,teks book, serta lingkungan di tempat sekolah ialah media. Terkhususnya, arti media di dalam pembelajaran ialah usaha dalam belajar dan juga bisa kita artikan sebagai instrumen untuk mengungkapkan ilustratif, fotografis, serta bertujuan untuk membantu proses berlangsungnya kegiatan hingga tersusun informasi visual dan verbal (Sunzuphy, n.d.).

Media juga kita artikan sebagai elemen bahan dalam proes pembelajaran. Dan juga dapat kita katakan sebagai pemanfaatan secara maksimal seluruh elemen sistem dan sumber belajar yang digunakan untuk meraih tujuan dari pembelajaran. Lalu Hamidjojo mengatakan bahwa media adalah seluruh bentuk penghubung yang dipakai untuk menyebarkan atau memberi gagasan yang akhirnya gagasan tersebut sampai kepada penerima. Sedangkan menurut dua ahli lainnya, media merupakan semua wacana atau penghubung yang di gunakan untuk memberi atau menyampaikan suatu 
moral, dimana media tersebut ialah cara atau sarana dimana suatu sarana tersebut berjalan antara komuditor ke komunikan (Miftah, 2013).

Media belajar secara menyeluruh menurut para ahli ialah bahan untuk membantu pembelajaran mengajar di sekolah. Selainnya media pembelajaran ialah sesuatu yang didapat serta dipergunakan dengan perangsangan volume otak, perasa, pengertian serta mampu menunjukkan keterampilan pembelajaran hingga bisa memotivasi datangnya pembelajaran. Hal itu luas cukup menyeluruhkan arti referensi, alam, insan serta proses yang di manfaatkan untuk tujuan proses atau latihan pembelajaran. Sedangkan menurut Briggs (1977) media belajar ialah wahana tubuh untuk penyampaian isi/materi belajar misalnya: book, film, video dan lain sebagainya. Oleh sebab itu usaha pembelajaran ialah cara komunikasi untuk berjalan suatu objek, sehingga media pembelajaran menduduki komponen yang amat penting sebagai suatu komponen sistem pembelajaran. Jika tidak dengan media, komunikasi yang kita lalukan tidak akan bisa terjadi dan juga proses pembelajaran yang menggunakan komunikasi juga tidak akan bisa berjalan dengan efektif (Luh \& Ekayani, 2021).

Di lingkup belajar mengajar, guru akan selalu berupaya memakai media pembelajaran semaksimal mungkin telah mengetahui betul fungsi dari media pembelajaran. Sebagai mana yang dikatakan Akbar fungsi dari media pembelajaran ialah menafsirkan penyampaian permintaan dan kabar serta meninggikan minat siswa sehigga menumbuhkan semangat belajar dan kegiatan secara langsung, mengurangi ketergantungan indra, ruang dan waktu dan juga membenarkan kepersisan situasi belajar siswa (Studi et al., 2018).

Media pembelajaran yang dapat dimanfaatkan pada suatu pendidikan adalah media pembelajaran yang berbasis multimedia integitas tinggi. Arti dari multimedia banyak sekali terkait dari cakupan aplikasi lalu dengan berkembangnya multimedia tersebut. Multimedia tidak hanya memiliki makna antara teks dan grafik yang sederhana saja, tetapi juga dilengkapi dengan suara, animasi, video, dan interaksi. Multimedia ialah pemenfaatan computer 
untuk membuat dan menggabungkan teks, grafik, audio, gambar bergerak (video dan animasi) dengan menggabungkan link dan tool yang memungkinkan pemakai melakukan navigasi, berinteraksi, berkreasi, dan berkomunikasi (Diah \& Nita, 2018).

Benime merupakan salah satu multimedia interaktif. Beni memerupakan aplikasi untuk mengedit video dan audio dan ada tambahan musik untuk latarnya untuk melahirkan kontenpembelajaran yang lebihluar biasa. Aplikasi ini memiliki tampilan yang sedehana yang di dalamnya ada beberapa templet untuk mengedit video maupun audionya. Kelebihan aplikasi ini adalah dapat membuat sejumlah video tanpa batasan apapun. Penelitian ini akan membahas membahas bagaimana manfaat dari aplikasi Benime dalam pembalajaran Mufradat, yang mana pembelajaran Mufradat ini adalah kunci utama dalam menguasai bahasa Arab. Dan dengan adanya aplikasi Benime diharapkan akan memberikan kontribusi yang penuh untuk mendukung hal tersebut.

\section{B. Metode Penelitian}

Penelitian kualitatif merupakan teknik penelitian yang dipakai dalam penelitian ini. Teknik penelitian kuantitatif merupakan jenis metode penelitian berbasis pradigma, yang bertimbangan bahwa penelitian mampu merencanakan dan mewujudkan peralihan tentang dunia sekitar dengan memenuhi berbagai tes (Abdullah, 2015). Dalam hal ini akan di gunakan aplikasi Benime sebagai media pembelajaran mufradat siswa kelas 1 di MIN 1 solok. Cakupan pembahasan mengenai pengumpulan data-data dari hasil observasi lapangan dan penjelasan menu yang ada di Benime serta cara penggunaan aplikasi tersebut.

\section{Hasil dan Pembahasan}

Bahasa Arab ialah salah satu bahasa internasional yang mempunyai kedudukan istimewa terurama di Indonesia. Awal mula untuk menguasai bahasa Arab yaitu dengan hafal mufradat dari bahasa Arab itu sendiri. Namun sangat di sayangkan minat dari siswa kurang baik untuk menghafal mufradat 
bahasa Arab. Hal tersebut di karenakan pembelajaran bahasa Arab kurang menarik bagi siswa apalagi siswa kelas satu yang kadang kurang faham membaca al-quran. Hal tersebut bisa membuat siswa tidak bersemangat untuk belajar bahasa arab. Jika media di tautkan melalui pembelajaran bahasa Arab sehingga di artkikan semua gambaran dialog bersama perangkat yang di gunakan pendidik dalam kegiatan pembelajaran untuk memudahkan siswa (Hilmi, 2017).

Media adalah salah satu elemen yang berlaku untuk perolehan maksud dari pembelajaran dalam keadaan tersebut boleh diperhatikan bahwa salah satu kewajiban istimewa media pembelajaran adalah sebagai perlengkapan belajar-mengajar yang menumpang mempengaruhi Ambisi syarat dan kawasan belajar penggunaan media dalam sistem pembelajaran mampu menumbuhkan kesenangan dan aspirasi yang baru menumbuhkan Ambisi dan menyangkal gerakan aktivitas belajar dan justru membawa konsekuensi terhadap intelektual peserta didik(Angraini, 2017).

Media pembelajaran juga berfungsi sebagai media yang komunikatif, komunikasi, mempunyai fungsi yang bermakna, dan fungsi persepsi. pada hal nya, media pembelajaran merupakan sesuatu yang sangat urgent untuk menunjang proses pembelajaran. Terlebih menjadi pendidik di era kemajuan teknologi, juga harus mempunya media pembelajaran yang sesuai dengan zaman sehingga mengahsilkan pembelajaran yang efektif dan efisien. Salah satu pemanfaatan kemajuan teknologi dalam pembelajaran bahasa arab khusunya dalam mufradat yaitu aplikasi Benime.

Benime merupakan aplikasi editor video dan ukiran tulisan semacam kata-kata dan juga di iringi dengan music dan audio yang mudah di pahami. Benime memakai sketsa animasi yang menyajikan presentasi deng ilustrasi gambar pada latar putih, yaitu sebuah media presentasi menggunakan layar seperti papan tulis dan animasi tangan yang bergerak menulis atau menggambar sesuatu sesuai objek yang ada di layar, software inibisa di akses di adroid ataupun PC. 
Keunggulan aplikasi ini adalah:

1. Bisa di akses dengan gratis di playstore dan appstore

2. Sangat aplikatif

3. Tampilan aplikasi yang sederhana dan simple serta mudah di pahami

4. Bisa di gunakan ketika offline

Berikut langkah-langkah untuk mengakses aplikasi Benime di android maupun di PC dan kegunaan tool di dalam aplikasi.

1. Buka crome bagi yang menggunakan PC dan playstore untuk yang menggunakan android

2. Selanjutnya ketik Benime di kolom pencarian

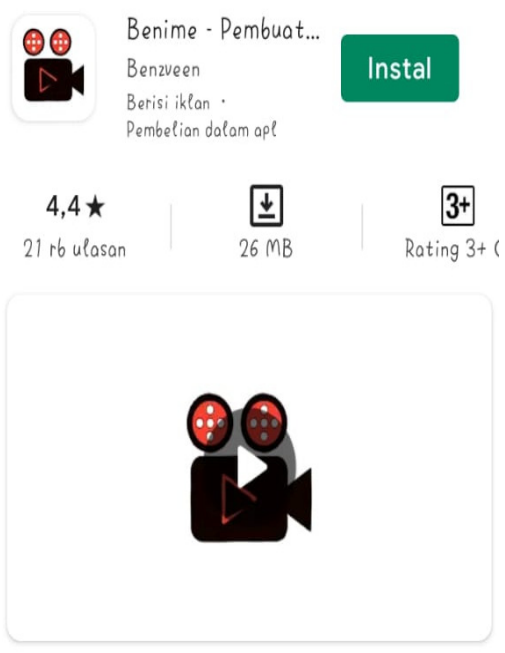

Buat video animasi papan tulis tanpa batas

Gambar 1. Searching Benime playstore sebelum mendonwload Kemudian klik kata install di seblah kanan aplikasi 


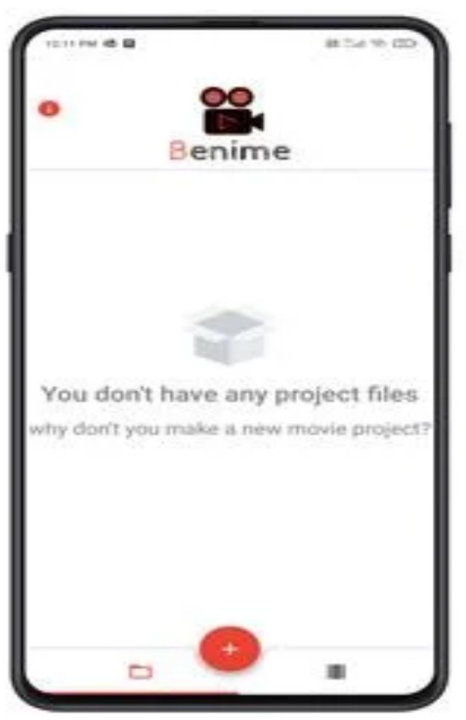

Gambar 2. Beginilah tampilan awal aplikasi Benime

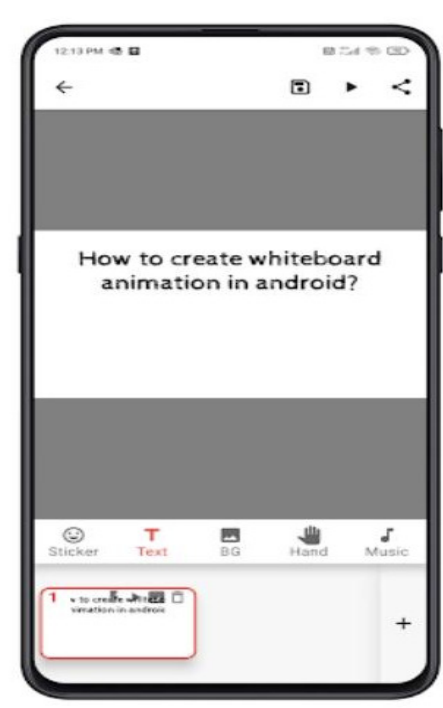

Gambar 3.Beberapa tool asset bawaan

Pada gambar di atasa terdapat beberapa tool atau menu yang bisa di gunakan. Di mulai dari sebelah kiri yaitu gambar smile dengan tulisan sticker, di dalam tool tersebut terdapat beberapa sticker yang bisa di gunakan pada pengeditan. Selanjutnya dari sebelah kiri yang kedua ada gambar huruf (T) dengan tulisan teks, pada tool ini kita bias menggunakan untuk menambahkan teks yang ingin di buat. Kemudian pada gambar ketiga ada gambar seperti lambang gallery dan tulisan (BG) yang mana kita dapat mengimpor SVG, animasi, dan gambar khusus dari penyimpanan lokal. Selanjutnya ada gambar 
jari dan tulisan (hand) yang mana kita bisa menambahkan animasi tangan bergerak pada papanatau white board. Lalu yang terakhir dari sebelah kiri yaitu ada gambar musik yang di gunakan untuk menambah music pada video yang di edit.

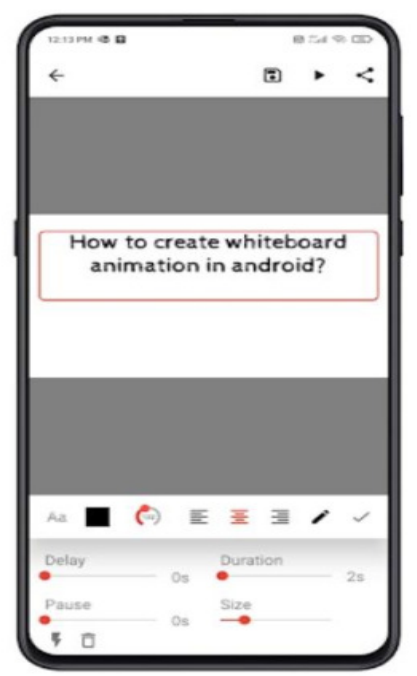

Gambar 4.Beberapa tool

Pada gambar di atas terdapat beberapa tool yang bisa di gunakan untuk mengedit video di antara nya:

1. Delay untuk menunda video yang di edit

2. Pouse untuk memberhentikan

3. Duration mengatur durasi

4. Size mengtur size dari video 


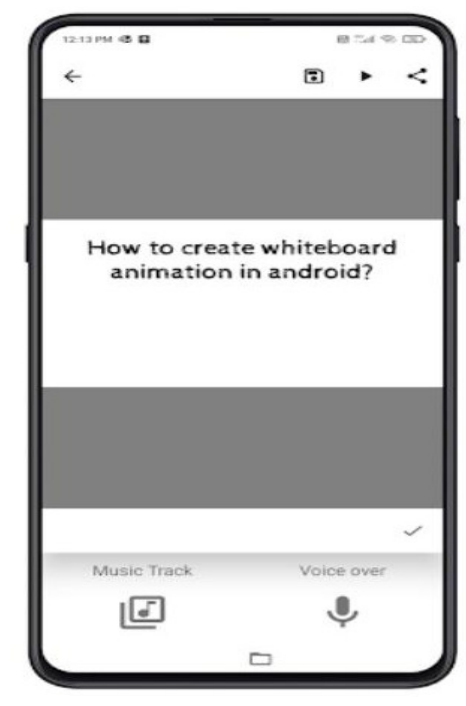

Gambar 5. Track dan voice

Tampilan gambar lima yaitu untuk menambahkan music track dan voice over pada video yang di edit

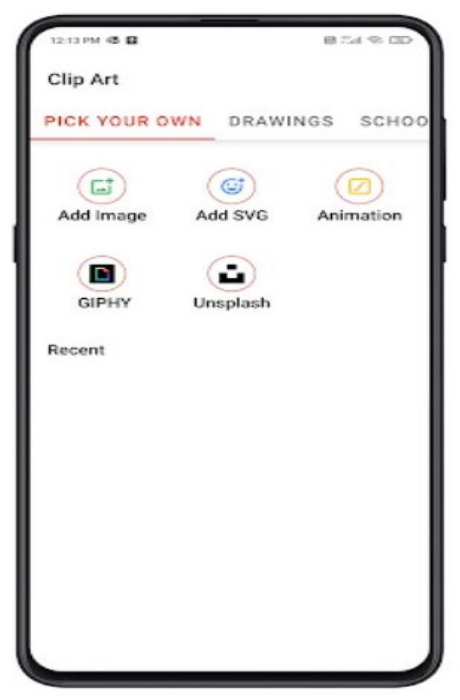

Gambar 6. Clip art

Pada tampilan gambar di atas yaitu ada beberapa (clip art) yang bisa di gunakan seperti: add image (mengimpor gambar dari local), add SVG, animation, dan juga bisa ghiphy dan unsplash. 


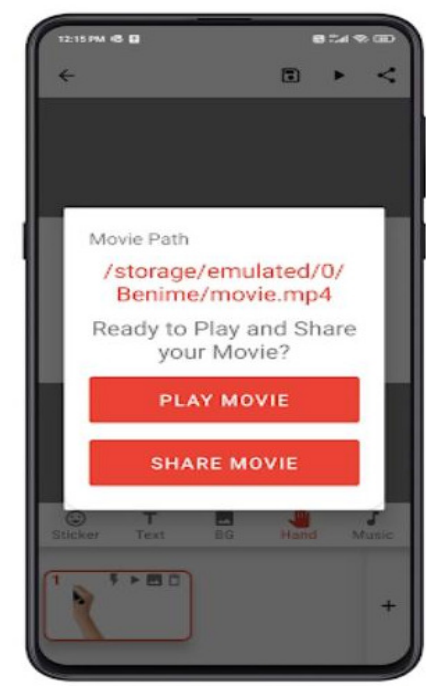

Gambar 7. Melihat video

Tampilan di atas yaitu unuk memulai menonton atau melihat video yng kita edit

Pada petunjuk diatas maka kita bisa membuat desain video pembelajaran mufradat yang menarik dan bisa menambahkan beberapa teks, hal ini bisa memberikan manfaat yang besar untuk meningkatkan kemampuan mufradat peserta didik. Sesuai dengan dengan yang disampaikan oleh guru bahasa Arab, bahwa aplikasi Benime ini sangat membantu dalam memberikan materi pelajaran, karena video yang dibuat mengandung unsur animasi dan sesuai dengan buku pelajaran.

\section{Kesimpulan}

Masa saat sekarang ini, zaman terus berkembang baik itu di bidang teknologi, industry, dan lainnya. Perkembangan ilmu pengetahuan dan teknologi juga mengiringi perkembangan zaman. Apalagi sekarang kita hidup di zaman 5.0 yang orang sudah bisa menaklukan masalah dunia dengan pengaplikasiannya dari perkembangan di era 4.0 yaitu internet. Yang semakin berjalan nya waktu semakin pesat perkembangannya. Berdampak pada semua aspek kehidupan salah satunya pendidikan. Semakin pesat nya perkembangan zaman tentunya juga di barengi dengan perkembangan dan inovasi dunia pendidikan. Dengan memanfaat kan software Benime merupakan hal yang 
sangat bisa di gunakan untuk era pembelajaran berbasis teknologi dan akan berdampak positif pada hasil pembelajaran. Apalagi dengan vitur yang sangat menarik yang di sediakan dan juga sederhana pengguanaannya yang memungkinkan sekali untuk menrik perhatian dan minat peserta didik sehingga tercapai tujuan dari pembelajaran yang di inginkan. Pemanfaatan software sebagai media pembelajaran membawa dampak positif tidak hanya pada pendidik namun juga kepada oeserta didik. Sebagai pendidik bisa mengolah media pembelajaran yang disesuaikn dengan perkembangan zaman. Terlebih sebagian besar peserta didik sudah bisa mengakses internet denganmudah. Peranan software Benimese bagai media pembelajaran pad era 5.0 merupakan hal yang sangat strategis karena bisa di akses dari mana saja dan kapan saja yang berguna untuk mempersiapkan generasi yang mampu dalam menghadapi perkembangan teknologi industri yang penuh dengan rintangan. 


\section{DAFTAR PUSTAKA}

Abdullah, P. M. (2015). Living in the world that is fit for habitation : CCI's ecumenical and religious relationships. In Aswaja Pressindo.

Akbar, A., \& Noviani, N. (2019). Tantangan dan Solusi dalam Perkembangan Teknologi Pendidikan di Indonesia. Prosiding Seminar Nasional Pendidikan Program Pascasarjana Universitas Pgri Palembang, 2(1), 18-25.

Albantani, A. M. (2018). Pembelajaran Bahasa Arab di Madrasah Ibtidaiyah: Sebuah Ide Terobosan. Attadib Journal Of Elementary Education, 3(2), 160-173.

Angraini, R. (2017). Karakteristik Media Yang Tepat Dalam Pembelajaran Pendidikan Kewarganegaraan (Pkn) Sebagai Pendidikan Nilai. Journal of Moral and Civic Education, 1(1), 14-24. https://doi.org/10.24036/8851412020171116

Bahri, S. (2017). Pengembangan Kurikulum Dasar Dan Tujuannya. Jurnal Ilmiah Islam Futura, 11(1), 15. https://doi.org/10.22373/jiif.v11i1.61

Diah, I., \& Nita, S. (2018). Pembuatan Video Sebagai Media Pembelajaranuntuk Meningkatkan Pemahaman Mahasiswa. DoubleClick: Journal of Computer and Information Technology, 1(2), 68-75. http://ejournal.unipma.ac.id/index.php/doubleclick

Emtha. (2014). Kerangka Dasar Kurikulum. Emtha'S Blog, 1. https://emtha1110.blogspot.com/2014/05/kerangka-dasar-kurikulum-2013.html

Hanafy, M. S. (2014). Konsep Belajar Dan Pembelajaran. Lentera Pendidikan : Jurnal Ilmu Tarbiyah Dan Keguruan, 17(1), 66-79. https://doi.org/10.24252/lp.2014v17n1a5

Hasanah, N. (2015). Dampak Kompetensi Profesional Guru Dalam Meningkatkan Mutu Pendidikan Madrasah Ibtidaiyah Di Kota Salatiga. Inferensi, 9(2), 445. https://doi.org/10.18326/infs13.v9i2.445-466

Hasbulloh, A. H. (2018). SKRIPSI Diajukan Kepada Fakultas Tarbiyah dan Ilmu Keguruan IAIN Purwokerto Untuk Memenuhi Salah Satu Syarat Guna Memperoleh Gelar Sarjana Pendidikan ( S . Pd .). 12.

Helmanto, F. (2020). Flashcard: Belajar Mufrodat Bahasa Arab Semakin Menantang. Tatsqifiy: Jurnal Pendidikan Bahasa Arab, 1(2), 141. https://doi.org/10.30997/tjpba.v1i2.3091

Hermawan, Y. C., Juliani, W. I., \& Widodo, H. (2020). Konsep Kurikulum Dan Kurikulum Pendidikan Islam. Jurnal MUDARRISUNA: Media Kajian Pendidikan Agama Islam, 10(1), 34. https://doi.org/10.22373/jm.v10i1.4720

Hijriyah, U. (2018). Analisis Pembelajaran Mufradat dan Struktur Bahasa Arab di Madrasah Ibtidaiyah.

Hilmi, H. (2017). Efektivitas Penggunaan Media Gambar Dalam Pembelajaran Bahasa 
Arab. Lantanida Journal, 4(2), 128. https://doi.org/10.22373/lj.v4i2.1885

Ibrahim, R. (2013). PENDIDIKAN MULTIKULTURAL: Pengertian, Prinsip , dan Relevansinya dengan Tujuan Pendidikan Islam. Addin, 7(1), 1-26.

Jennah, R. (2009). L: Llltlltlill. In Media Pembelajaran.

Julaeha, S. (2019). Problematika Kurikulum dan Pembelajaran Pendidikan Karakter. $\begin{array}{lllll}\text { Jurnal Penelitian } & \text { Pendidikan }\end{array}$ https://doi.org/10.36667/jppi.v7i2.367

Kirom, A. (2017). Peran Guru Dan Peserta Didik Dalam Proses Pembelajaran. Al Murabbi $3(1)$, 69-80. http://jurnal.yudharta.ac.id/v2/index.php/pai/article/view/893

Luh, N., \& Ekayani, P. (2021). Pentingnya penggunaan media siswa. Pentingnya Penggunaan Media Pembelajaran Untuk Meningkatkan Prestasi Belajar Siswa, March, 1-16.

Mada, A. S. K. (2018). Upaya Peningkatan Kosakata Bahasa Arab Bagi siswa Kelas V Madrasah Ibtidaiyah Fie Sabilil Muttaqien Ngarengan Kedunggalar Ngawi. http://etheses.iainponorogo.ac.id/4206/1/Mada PDF.pdf

Miftah, M. (2013). Fungsi, Dan Peran Media Pembelajaran Sebagai Upaya Peningkatan Kemampuan Belajar Siswa. Kwangsan: Jurnal Teknologi Pendidikan, 1(2), 95. https://doi.org/10.31800/jtp.kw.v1n2.p95--105

Nurdyansyah, N. (2017). Sumber Daya dalam Teknologi Pendidikan. Universitas Negeri Surabaya, 1-22. http://eprints.umsida.ac.id/1625/1/Sumber Daya dalam Teknologi Pendidikan.pdf

Nurjati, S. (2002). Bab ii pembelajaran akidah akhlak, basis humansitik, pendekatan active learning. 39-104.

Studi, P., Sejarah, P., Pendidikan, F., Sosial, I., \& Naharuddin, M. (2018). Penerapan Media Pembelajaran Berbasis Multimedia Interaktif Terhadap Mahasiswa IKIP Budi Utomo Malang Pendahuluan. 8(2), 188-198.

Sunzuphy, C. (n.d.). Media pembelajaran.

Suriansyah, A. (2011). Landasan Pendidkan. Comdes, 13. http://idr.uinantasari.ac.id/6633/1/Buku Landasan Pendidikan.pdf

Takdir, T. (2020). Problematika Pembelajaran Bahasa Arab. Jurnal Naskhi: Jurnal Kajian Pendidikan Dan Bahasa Arab, 2(1), 40-58. https://doi.org/10.47435/naskhi.v2i1.290

Wafi, A. (2017). Konsep Dasar Kurikulum Pendidikan Agama Islam. Edureligia; Jurnal Pendidikan Agama Islam, 1(2), 133-139. https://doi.org/10.33650/edureligia.v1i2.741

Wahidin, U. (2017). Pendidikan Karakter Bagi Remaja. Edukasi Islami : Jurnal Pendidikan Islam, 2(03). https://doi.org/10.30868/ei.v2i03.29 
